\title{
THE ECONOMIC ANALYSIS OF CRAYFISH PROCESSING IN AKWA IBOM STATE, NIGERIA
}

\author{
AHAMEFULE BA*, OKPARA BO, PETER LI
}

Department of Agricultural Economics, Michael Okpara University of Agriculture Umudike, P.M.B 7267 Umuahia, AbiaState, Nigeria Email: blessingahamefuleada@gmail.com

Received: 24 March 2021, Revised and Accepted: 14 September 2021

ABSTRACT

Objectives: Crayfish production is a source of both direct and indirect employment. It is a major income generating activity that offers substantial economic benefits to traders and has the potential to address food security problems. Hence, the work analyzed the profitability of crayfish production and the determinants while highlighting the constraints to crayfish production.

Methods: The multistage random sampling procedure was used to select 120 crayfish producers. Quantitative analytical techniques were employed in the analysis. Socioeconomic characteristics and constraints were assessed using descriptive statistical tools, while the level of profit and its determinants were evaluated using the farm budgeting technique and ordinary least square multiple regression techniques, respectively.

Results: Crayfish production is a profitable venture with a return on investment of $45,585.1$. Primary occupation, household size, processing experience, and quantity processed positively affected the performance of the enterprise while labor cost, association membership, and processing costs negatively influenced the enterprise.

Conclusion: Efficiency of resource use, enhanced profitability, and livelihoods can be achieved through the provision of infrastructures and improved processing equipment at subsidized rates.

Keywords: Crayfish processing, Performance, Profitability, Production.

(C) 2021 The Authors. Published by Innovare Academic Sciences Pvt Ltd. This is an open access article under the CC BY license (http://creativecommons. org/licenses/by/4.0/) DOI: http://dx.doi.org/10.22159/ijags.2021v9i6.41591. Journal homepage: https://innovareacademics.in/journals/index.php/ijags

\section{INTRODUCTION}

Fish and fish products are among the most traded food items in the world today. According to FAO (2018), about 35\% of global fish production entered international trade in various forms for human consumption or non-edible purpose in 2016. Crayfish production is mostly wild caught and not farmed in Africa, though about 5000 tonnes live weight of crustacean species were produced from marine and coastal aquaculture [1]. The report also stated that catch statistics for freshwater crustaceans (like crayfish) and freshwater mollusc had peaks in the early 2000 and mid-1990s, respectively, but after periods of decreasing catches, they have been relatively stable since 2010 at 0.45 and 0.36 million tonnes.

The Nigeria Fisheries subsector contributes about 3-4\% to the country's annual gross domestic product and is an important contributor to the population's nutritional requirements constituting about $50 \%$ of animal protein intake [2]. The subsector generates employment and income for a significant number of artisanal fishermen and small traders. In spite of this huge potential that Nigeria has in both marine and freshwater fisheries, including aquaculture, domestic fish production still falls far below the total demand. However, many people in the country today engage in the production and marketing of crayfish as a livelihood due to its high demand in the markets.

Crayfish are a freshwater crustacean resembling small lobsters/ shrimps and are also known as crawfish, crawdads, freshwater lobsters, mountain lobsters, mudbugs, or yabbies (Wikipedia). Although the artificial rearing and production of crayfish in Nigeria is not common compared to the production of fish, the processing and packaging of shrimp is gaining ground because of the advantage it presents to most housewives in Nigeria. Food containing crayfish play an important role in the development of humans, especially in the lives of people in the developing countries where other sources of protein are highly inadequate and expensive [3]. Some rural dwellers substitute crayfish for meat in their meals as a source of protein. Evidence shows that $54.3 \%$ of crayfish are made up of protein [4] and it is a clean and very low carbohydrate food [5].

Crayfish are usually caught in baited wire mesh between March and October when they are at peak quality. Yields of crayfish from fishing (wild caught) can vary depending on the species, season, processing technique, and other factors. None of the catches is discarded no matter how small in this part of the world. Crayfish key roles and attributes in the ecosystem include indicators or surrogates for water quality, bio-indicators for communities or habitats, keystone controllers of tropical webs, and ecological engineers [6]. Protected crayfish may act as umbrella species for the conservation of communities [7] and also play a crucial role in food chain by feeding on living and dead plants and smaller creatures in addition to serving as food for fish and other mammals. In Nigeria, processed crayfish consist of post-larvae stages of pink shrimps [8], in addition to mixtures of crayfish, small prawns/ shrimps, and other crustaceans harvested from estuaries and rich coastal waters. This crustacean can be sourced in abundance from Akwa Ibom and Cross River States, respectively, and enjoys wide patronage locally from operators of restaurants, bukateria, and hotel. More so, crayfish harvesting, production, and marketing in Akwa Ibom State have provided business and economic activities for the people and crayfish dealers [3] in coastal regions where crayfish are found in abundance. For instance, crayfish production is a source of both direct and indirect employment. This includes jobs associated with gear sales/repairs, crayfish capture/harvesting, processing for local and export markets, and cold storage facilities [9]. Furthermore, these and other value chain activities will help to reduce post-harvest losses, and boost economic returns from crayfish enterprise. Hence, crayfish 
production is a major income generating activity that offers substantial economic benefits to traders and has the potential to address food security problems. Therefore, this work examined the socioeconomic characteristic of the respondents in the study area, analyzed the level of profit of crayfish production and the determinants while highlighting the constraints to crayfish production in the study area.

\section{MATERIALS AND METHODS}

The research was conducted in Akwa Ibom State. Trigonometrically, Akwa Ibom State lies between latitude $4^{\circ} 31^{1}$ and $5^{\circ} 53^{1}$ North, and longitudes $7^{\circ} 23^{\mathrm{I}}$ and $8^{\circ} 25^{\mathrm{I}}$ east. In terms of structural make up, Akwa Ibom is triangular in shape and cover a total land area of 8412 square kilometer with a total population size of 3,920,2089 [10]. The state is bothered on the west by Rivers State and Abia State, on the South by the Atlantic Ocean and the southernmost tip of Cross River State. The area is favorable for livestock and fish production. Hence, most of the inhabitants are either full time or part-time livestock or fish farmers. The fishermen also harvest crayfish, periwinkle, and fishes in large quantity. The state consists of 31 local government areas and six agricultural zones, namely, Oron, Abak, Ikot Ekpene, Etinan, Eket and Uyo agricultural zones [11].

A multistage random sampling procedure was used in selecting the respondents. The first step involved the purposive selection of two agricultural zones, namely, Eket and Uyo from the existing six that make up the state. In the second stage, two local government areas were purposively selected from each of the zones (Onna and Ibeno in Eket; Uyo and Uran in Uyo) giving a total of four local government areas. In the third stage, three communities were purposively selected

Table 1: Socioeconomic characteristics of the respondents

\begin{tabular}{|c|c|c|}
\hline Variable & Frequency & Percentage of total \\
\hline \multicolumn{3}{|l|}{ Age } \\
\hline $18-30$ & 53 & 42.5 \\
\hline $31-40$ & 44 & 36.6 \\
\hline $41-50$ & 19 & 15.8 mean=29 \\
\hline $51-6$ & 4 & 3.3 \\
\hline \multicolumn{3}{|l|}{ Sex } \\
\hline Male & 8066.7 & \\
\hline Female & 40 & 33.3 \\
\hline \multicolumn{3}{|l|}{ Household size } \\
\hline $1-4$ & 22 & 18.3 \\
\hline $5-8$ & 34 & 28.4 Mean=8 \\
\hline $9-12$ & 46 & 38.3 \\
\hline $13-17$ & 8.4 & 15.1 \\
\hline \multicolumn{3}{|l|}{ Level of education } \\
\hline No formal education & 18 & 15 \\
\hline Primary education & 48 & 39.9 \\
\hline $\begin{array}{l}\text { Secondary } \\
\text { education }\end{array}$ & 46 & 38.4 \\
\hline Tertiary education & 8 & 6.7 \\
\hline \multicolumn{3}{|l|}{ Processing experience } \\
\hline $1-5$ & 34 & 28.3 \\
\hline $6-10$ & 48 & 37 \\
\hline $11-15$ & 21 & 15.8 Mean=10.6 \\
\hline $16-20$ & 7 & 5.7 \\
\hline $21-25$ & 6 & 5 \\
\hline $26-30$ & 6 & 5 \\
\hline \multicolumn{3}{|l|}{ Marital status } \\
\hline Single & 49 & 40.8 \\
\hline Married & 61 & 50.8 \\
\hline Divorced & 6 & 5.0 \\
\hline Widow/widower & 4 & 3.3 \\
\hline \multicolumn{3}{|l|}{ Primary occupation } \\
\hline Crayfish processing & 57 & 47.5 \\
\hline Crop farmers & 63 & 52.5 \\
\hline \multicolumn{3}{|l|}{ Cooperative } \\
\hline Members & 47 & 39.2 \\
\hline Non-member & 73 & 60.8 \\
\hline
\end{tabular}

from each of the LGAs which are Nung Ndem, Oniong, and Awa from Onna LGA; Iwokpom, Inuayerikot, and Nkpanak from Ibeno LGA; Ikono, Offot, and Oku from Uyo LGA; and North Uran, South Uran, and Central Uran from Uran LGA, giving a total of 12 communities. In stage four, 10 crayfish farmers were purposively selected from each community giving a total of 120 producers for the study. The purposive selection done at each stage aimed at capturing areas and people who were more involved in catching/harvesting, processing, and production of crayfish in the state. Relevant data for the study were collected from the respondents through the use of structured questionnaire that was administered by the researcher and other research assistants to the producers.

\section{Analytical techniques}

Data from this study were analyzed using different tools and technique. Quantitative analytical techniques were employed to achieve the objectives. Specifically, the descriptive statistics and the constraints were analyzed using statistics tools such as means and percentages. The level of profit and its determinants were analyzed using the farm budgeting technique employed by [12] and the ordinary least square multiple regression technique.

$\mathrm{GM}=\mathrm{GR}-\mathrm{T}$

Where; GM = Gross margin in naira per $\mathrm{kg}$

$\mathrm{GR}=$ Gross revenue in naira

TVC $=$ Total variable cost in naira

$\mathrm{NI}=\mathrm{TR}-\mathrm{TC}$

The result of the budgetary analysis was used to obtain the following ratios;

$\mathrm{RRI}=$ Rate of return on investment $=\frac{N I}{T C}, \frac{100}{1}$

Where; $\mathrm{NI}=$ Net income

$\mathrm{TR}=$ Total revenue

$\mathrm{TC}=$ Total cost

$\mathrm{TFC}=$ Total fixed cost

The profit function was fitted into the data and estimated using the multiple regression technique. The various forms of regression model were used to examine the influence of socioeconomic characteristics on profit level. The model is implicitly expressed as:

$Y=f\left(x_{1}, x_{2}, x_{3}, x_{4}, x_{5}, x_{6}, e\right)$

Table 2: Cost and return analysis of crayfish production

\begin{tabular}{lll}
\hline Items & $\begin{array}{l}\text { Unit } \\
\text { cost (N) }\end{array}$ & $\begin{array}{l}\text { Average } \\
\text { value (N) }\end{array}$ \\
\hline $\begin{array}{ll}\text { (A) Output and values of output } \\
\text { 13.1 bags of crayfish (50 kg) }\end{array}$ & 7000 & $91,408.3$ \\
$\begin{array}{l}\text { (b) Input and values of input } \\
\text { Variable cost }\end{array}$ & \\
$\quad$ Transport & \\
$\quad$ Preservation & 3528.6 \\
$\quad$ Processing & 4658.0 \\
Fixed cost & 11645.0 \\
Depreciation & \\
Total cost=TVC+TFC & 3080 \\
Gross margin=TR-TVC & $22,911.6$ \\
Net return & $71,576.7$ \\
Return on & $68,496.7$ \\
investment (RI)=NR-TC & $45,585.1$ \\
Net income=GM-FC & \\
\hline
\end{tabular}


Table 3: Estimates of the regression analysis showing factors that affected the profitability of crayfish production

\begin{tabular}{|c|c|c|c|c|}
\hline Variable & Linear & Exponential & Semi-log & Double log+ \\
\hline \multirow[t]{2}{*}{ Constantw } & 4.555 & 0.000 & 0.788 & 0.002 \\
\hline & $(0.000)$ & $(34.263)^{* * *}$ & $(-0.270)$ & $(4.575)^{* * *}$ \\
\hline \multirow[t]{2}{*}{ Age $\left(X_{1}\right)$} & 0.876 & 0.396 & 0.329 & 0.396 \\
\hline & $(0.156)$ & $(0.851)$ & $(0.981)$ & $(0.854)$ \\
\hline \multirow[t]{2}{*}{ Marital status $\left(\mathrm{X}_{2}\right)$} & 0.623 & 0.429 & 0.941 & 0.825 \\
\hline & $(-0.492)$ & $(-0.704)$ & $(-0.074)$ & $(-0.221)$ \\
\hline Educ. level $\left(\mathrm{X}_{3}\right)$ & 0.383 & 0.103 & 0.846 & 0.898 \\
\hline Primary & 0.810 & 0.022 & 0.760 & 0.050 \\
\hline occupation $\left(\mathrm{X}_{4}\right)$ & $(-1.761)$ & $(2.323)^{* *}$ & $(-1.796)$ & $(1.987)^{*}$ \\
\hline \multirow{2}{*}{ Household size $\left(\mathrm{X}_{5}\right)$} & 0.000 & 0.001 & 0.013 & 0.011 \\
\hline & $(3.868)^{* * *}$ & $(3.576)^{* * *}$ & $(2.530)^{* *}$ & $(2.585)^{* *}$ \\
\hline \multirow[t]{2}{*}{ Processing exp. $\left(\mathrm{X}_{6}\right)$} & 0.001 & 0.003 & 0.076 & 0.054 \\
\hline & $(3.465)^{* * *}$ & $(3.026)^{* * *}$ & $(-1.796)^{*}$ & $(1.953)^{*}$ \\
\hline \multirow[t]{2}{*}{ Labor $\left(X_{7}\right)$} & 0.000 & 0.000 & 0.000 & 0.000 \\
\hline & $(-4.987)^{* * *}$ & $(-4.434)^{* * *}$ & $(-4.609)^{* * *}$ & $(-4.927)^{* * *}$ \\
\hline processed $\left(\mathrm{X}_{8}\right)$ & (1.055) & (1.001) & $(0.192)$ & $(2.454)^{* *}$ \\
\hline Cooperative & 0.003 & 0.216 & 0.018 & 0.018 \\
\hline member $\left(\mathrm{X}_{9}\right)$ & $(-3.087)^{* * *}$ & $(-1.246)$ & $(-2.412)^{* *}$ & $(-2.458)^{* *}$ \\
\hline \multirow[t]{2}{*}{ Transport cost $\left(\mathrm{X}_{10}\right)$} & 0.132 & 0.055 & 0.237 & 0.451 \\
\hline & $(-1.519)$ & $(1.937)^{*}$ & $(-1.191)$ & $(-0.758)$ \\
\hline Processing & 0.865 & 0.042 & 0.155 & 0.003 \\
\hline $\operatorname{cost}\left(X_{11}\right)$ & $(-0.173)$ & $(-2.059)^{* *}$ & $(1.436)$ & $(-3.067)^{* * *}$ \\
\hline $\mathrm{R}^{2}$ & 0.656 & 0.776 & 0.601 & 0.809 \\
\hline $\mathrm{R}-{ }^{2}$ & 0.621 & 0.753 & 0.552 & 0.785 \\
\hline F-ratio & $18.696^{* * *}$ & $33.987^{* * *}$ & $12.211^{* * *}$ & $73.298^{* * *}$ \\
\hline
\end{tabular}

Source: Field survey. ${ }^{* * *}, * * *$, and + represent significant at $1 \%, 5 \%$, and $10 \%$ and lead equation, respectively

Table 4: Constraints faced by crayfish processors

\begin{tabular}{llll}
\hline Problems & Frequency* $^{*}$ & Percentage total & Rank \\
\hline Inadequate storage facility & 40 & 33.3 & 5 \\
Inadequate processing & 80 & 66.7 & 1 \\
facility & & & \\
High cost of transportation & 49 & 40.8 & 4 \\
Adverse weather & 80 & 66.7 & 1 \\
Inadequate capital & 61 & 50.8 & 3 \\
Sex discrimination & 18 & 15 & 6 \\
\hline
\end{tabular}

Source: Field survey. * Multiple response

Explicitly, the model is stated thus;

$$
\mathrm{Y}=\mathrm{b}_{0}+\mathrm{b}_{1} \mathrm{X}_{1}+\mathrm{b}_{2} \mathrm{X}_{2}+\mathrm{b}_{3} \mathrm{X}_{3}+\mathrm{b}_{4} \mathrm{X}_{4}+\mathrm{b}_{5} \mathrm{X}_{5}+\mathrm{b}_{6} \mathrm{X}_{6} \ldots \mathrm{b}_{\mathrm{n}} \mathrm{X}_{\mathrm{n}}+\mathrm{e}
$$

Where;

$\mathrm{Y}=$ Profit $(\mathrm{A})$

$\mathrm{X}_{1}=$ Age $($ years $)$

$\mathrm{X}_{2}=$ Marital status

$\mathrm{X}_{3}=$ Educational level (years)

$\mathrm{X}_{4}=$ Primary occupation

$\mathrm{X}_{5}=$ Household size (number of person)

$\mathrm{X}_{6}=$ Production experience (years)

$\mathrm{X}_{7}=$ Labor wage $(\mathrm{A})$

$\mathrm{X}_{8}=$ Quantity produced $(\mathrm{kg})$

$\mathrm{X}_{9}=$ Membership

$\mathrm{X}_{10}=$ Transport cost ( $\left.\mathrm{N}\right)$

$\mathrm{X}_{11}=$ Production cost $(\mathrm{N})$

$\mathrm{e}=$ Error term

Four functional forms of the regression model, namely; the linear, double logarithm, semi-logarithm, and the exponential functional forms were tried. The implicit forms are specified below:

$$
\text { Linear; } \mathrm{Y}=\mathrm{b}_{\mathrm{o}}+\mathrm{b}_{1} \mathrm{X}_{1}+\mathrm{b}_{2} \mathrm{X}_{2}+\mathrm{b}_{3} \mathrm{X}_{3}+\ldots \ldots+\mathrm{b}_{\mathrm{n}} \mathrm{X}_{\mathrm{n}}+\mathrm{u}
$$

$$
\begin{aligned}
& \text { Semi-log; } \mathrm{Y}=\mathrm{b}_{\mathrm{o}}+\mathrm{b}_{1} \log \mathrm{X}_{1}+\mathrm{b}_{2} \log \mathrm{X}_{2}+\mathrm{b}_{3} \log \mathrm{X}_{3}+\ldots \ldots+\mathrm{b}_{\mathrm{n}} \log \mathrm{X}_{\mathrm{n}}+\mathrm{u} \\
& \text { Double log; } \log \mathrm{Y}=\mathrm{b}_{\mathrm{o}}+\mathrm{b}_{1} \log \mathrm{X}_{1}+\mathrm{b}_{2} \log \mathrm{X}_{2}+\mathrm{b}_{3} \log \mathrm{X}_{3}+\ldots+\mathrm{b}_{\mathrm{n}} \log \mathrm{X}_{\mathrm{n}}+\mathrm{u} \\
& \text { Exponential } \log ; \log \mathrm{Y}=\mathrm{b}_{\mathrm{o}}+\mathrm{b}_{1} \mathrm{X}_{1}+\mathrm{b}_{2} \mathrm{X}_{2}+\mathrm{b}_{3} \mathrm{X}_{3}+\ldots \ldots+\mathrm{b}_{\mathrm{n}} \mathrm{X}_{\mathrm{n}}+\mathrm{u}
\end{aligned}
$$

\section{RESULTS AND DISCUSSION}

The result in Table 1 depicts that crayfish production was predominantly a male profession in the study area. This is because majority (80\%) of the respondents were male while $40 \%$ were female. Respondents with age bracket 21-30 years dominated crayfish production. The average age of the producers was 29 years. Implication of this finding is that large proportion of the respondents was young adults and can be regarded as active, agile, and physically disposed to the production activities and adoption of modern innovation which is capable of yielding higher income for the enterprise. Categories of production experience span from 1-5 years to 30 years with an average of 10.6 years.

More so, the mean household size of the producers is 8. The implication is that the processors in the study area have a large family size. The family might be exploited as cheap source of labor for the business enterprise. However, large family sizes might be a drain for business profit as household expenditure particularly on consumption is high. About $15 \%$ of the respondents interviewed had no formal education while $6.7 \%$ had tertiary education. Majority of the respondents (39.9\%) had primary education, whereas only $38.4 \%$ had their secondary education. The result shows that the educational attainment of crayfish processors in the study area is low, the implication is that the education level will be positively related to productivity. The occupation of the respondents in the study area shows that $47.5 \%$ engage in crayfish processing as their main occupation while majority (60.8\%) do not belong to any cooperative society.

\section{Profitability analysis of crayfish production}

The result of the profitability analysis of crayfish production in the study area is presented in Table 2 . 
The result in Table 2 indicates that crayfish processing is a profitable business in the study area. The total revenue was $\$ 91,408.3$ and the total cost was $22,911.6$, the net return was $\$ 68$, 496.7. The return on investment was $\$ 45,585.1$ and the net income was $\$ 68,496.7$

\section{Factors that influenced the profitability of crayfish production}

The estimates of the determinants of crayfish processing are summarized in Table 3. The results of the four functional forms were presented and the choice of lead equation was based on econometric and statistical reasons - the magnitude of the coefficient of multiple determination.

The regression result in Table 3 shows that there was a significant relationship (F-ratio $=73.298, \mathrm{R}^{2}=0.785$ ) between the socioeconomic features of the crayfish producers and their level of profit from the enterprise. The lead equation was chosen due to the conformity of the significant variables to a priori expectations and the goodness of fit of the regression model. Specifically, primary occupation and the quantity (bags) of crayfish produced were positively significant and influenced the level of profit of the respondents from crayfish enterprise. This means that changes in primary occupation and quantity (bags) of crayfish produced will change the income and those that engage in crayfish processing as their primary occupation seem to do well.

The positive significant relationship between the quantity (bags) of crayfish produced and the level of profit from crayfish enterprise is expected because profit from the business depends mostly on quantity of crayfish produced such that when more crayfish are produced, more bags of crayfish will be expected and hence more income. This confirms the study of Enang [3] that number of bags of fish/crayfish sold determines if the fish farmer is making a profit or loss.

Age, marital status, and number of years spent in acquiring education and transport cost did not influence the level of profit from the crayfish enterprise. This implies that these variables did not add to the ability to predict the level of profit realized from crayfish production in the study area.

\section{Constraint faced by crayfish processors}

Table 4 summarizes all the constraints encountered by the respondents in crayfish processing business.

Table 4 shows that inadequate processing facility and adverse weather condition with $66.7 \%$ of the respondents are the major constraint mitigating against crayfish processing. About 50.8\%, 40.8\%, 33.3, and $15 \%$ of the respondents also indicated that inadequate capital, high cost of transportation, inadequate storage facility, and sex discrimination are other constraints they encountered, respectively.

\section{CONCLUSION}

It could be concluded from this study that labor cost and processing cost are negatively affecting the volume of output and net returns while household size, processing experience, primary occupation, and labor cost are positively affecting the level of profit realized from crayfish enterprises in the study area. It is, therefore, recommended that the government should provide improved processing equipment at subsidized rates that will enable the processors produce crayfish efficiently, thereby enhancing profitability and reducing the cost of production. The construction of good access roads to the fishing communities will help reduce the high transportation costs incurred during the movement of crayfish products and attract potential investors who may wish to engage into crayfish production. Furthermore, enlightenment campaign through the mass media is necessary to awaken the youth at large on the promising return that is embedded in crayfish processing.

\section{REFERENCES}

1. Food and Agricultural Organization. The State of World Fisheries and Aquaculture; Meeting the Sustainable Development Goals. Rome: Food and Agricultural Organization of the United Nations; 2018. p. 1-227.

2. Food and Agricultural Organization. Nigeria at a Glance. FAO in Nigeria. Rome: Food and Agricultural Organization of the United Nations; 2020. Available from: https://www.fao.org.

3. Enang B. Analysis of Crayfish Price Relationship in Calabar. A Bachelor of Agriculture Dergree Dissertation of the Faculty of Agriculture. Calabar, Nigeria: University of Calabar; 2014.

4. Paxton M. Agriculture of Fresh water Crayfish-Cherax Destruction. Alabama, USA: Bellows Kenton Limited; 1995. p. 12-30.

5. Grace N. Crayfish Health Benefits; Health, Knowledge, Natural Food Matters in Nigeria. 2010. p. 48-68. Available from: http:/www. gracengofoundation.org.ng.2020/02/crayfish-healthbenefits.html.

6. Iwuchukwu JC, Eke JN, Udoye CE. Practices of farmers in processing and marketing of crayfish in Akwalbom State, Nigeria. Afr J Agric Res 2017; 12:3169-80.

7. Reynolds J, Souty-Grosset C, Richardson A. Ecological roles of crayfish in fresh water and terrestrial habitats. Fresh Water Crayfish 2013;19:197-218.

8. Asibong AE. Analysis of Crayfish Quantity and Price Relationship and Marketing Margin in Esuk Nsidung of Calabar South, Cross River State. A Bachelor of Agriculture Degree Dissertation to the Faculty of Agiculture. Calabar, Nigeria: University of Calabar; 1992.

9. Essuman J. Interstate Marketing of Crayfish: A Case Study of Crayfish Marketing in Imo State, B.Sc. Dissertation, Ethiopia. Maharashtra: A Funded Research Study Conducted for Economic and Social Research Consortium; 2009. p. 101.

10. National Population Commission. National Population Commison. Estimated Population Figures, Abuja. Nigeria: National Population Commission of Nigeria; 2006.

11. Ikono C. The Cradle of Ibibio: The Premium Herald. ???: ???; 2016. p. 24 .

12. Ibekwe UC, Chikezie C, Obasi PC, Eze CC, Henri-Ukaoha A. Profitability of Garri processing in Owerri North local government area of Imo state. ARPN J Sci Technol 2012;2:340-3. 